\title{
Science and Religion on the environmental crisis
}

\author{
Associate Professor PhD. Adrian IGNAT, \\ Valahia University, Târgoviște, \\ ROMÂNIA, \\ Email: adrianignat1974@yahoo.com
}

\begin{abstract}
The environmental crisis today becomes an issue with important impact on our world. Everyone understands that it is very important to protect the nature, to limit pollution, and to rise the respect for all forms of life. On the other side, the world is confronted with the growth of population. To feed all population becomes a challenge for the rulers of states, especially on the poor countries. Degraded land, eroded soil, and decimated fisheries and forests will take many years to recover. For that it is important to connect all the scientists and representatives of states, and also the religious leaders. Through this paper I will try to underline the common point of view of scientists and religious people on the environmental issue. This paper is not an exhaustive one, but emphasizes the possibility of collaboration and common action for the sake of this world.
\end{abstract}

Keywords: environment; crisis; religion; actions; Christian Church.

\section{INTRODUCTION}

From the starting point of this paper I must say that the members of scientific and religious communities work together for the future of this planet. From 1990 until now, a series of conferences was held under the title "Joint Appeal of Science and Religion for the Environment" $"$. This collaboration had as result some pragmatic considerations: people who share and express their concern can be more effective in education and political action if they work together.

These meetings gave the opportunity to know and to learn from each other. Examining the common points of view and the distinctive ones, the scientists and the religious members of community opened an interdisciplinary dialogue for the benefit of society.

\section{THE SCIENTIFIC CONTRIBUTION ON THE ECOLOGICAL CRISIS}

Presenting the point of view, science give us a complex understanding of the environmental impacts of our current agricultural, industrial and personal practices. The new discovers on the technical and industrial ground offer a new view of interdependence between humanity and nature. Nature is not an instrument, which can satisfy our wills, is a partner for the future. Without it we cannot exist.

Even if the scientists presented the impact of pollution on air, water and land on the 1960s and 1970s, on the 1980s and 1990s they made us aware of long-term global impacts:

\footnotetext{
1 Andrey Chapman and Rodney Petersen, Consumption, Population and Sustainability: perspective from Science and Religion (Covelo, Calif: Island Press, 2000).
} 
the climate changes and the loss of endangered species ${ }^{2}$. The intensive agriculture eroded the topsoil, and had contributed to the deforestation of planet. Some studies sustained that the world population is growing up 80 million each year ${ }^{3}$.

The theory of Thomas Robert Malthus, Anglican priest and professor of economy, is starting from the hypothesis of growth of population and the limitation of resources ${ }^{4}$. For that it is necessary some wars and epidemics to limit the growth of population. Against his theory has fought Christian theologians from different traditions: Orthodox, Catholic or Protestant. They believe that human being has the right to live; even if the natural resources are limited, the science has developed or will develop the necessary technology to supply that. More than that, on the world there are a lot of waste of natural resources. A better administration of that, a good understanding of our role in the world will help to prevent the waste.

Other scientists recommend some particular policies of action based on the scientific estimates of the consequences of that policies. But the scientific proposals not always become laws on the state's decisions. On the other hand, the scientific proposals give advantage through the technology and economic policy to a group of citizens, not to all. Usually, the main burden of risks or indirect costs are supported by all. "Policy decisions thus require ethical analysis and input from the social sciences and the wider culture as well as input from the natural sciences, even when the latter are as crucial as they are in decisions affecting the environment and sustainability".5.

The scientific community showed that there is an interdependence of all forms of life. While some ecosystems are resilient, others are vulnerable and fragile on the human actions. Diversity in the biosphere allows for both stability and adaptation to new conditions.

Our life style has many consequences over the environment. The future generations must deal with the impact of our technology: radioactive wastes from nuclear power plants; intensive agriculture; deforestation; pollution of the soil, waters and air; disappears of many species of plants, fishes and animals; global overwarming etc. Faced with that challenges, science tries to give an adequate response. For that members of scientific community have committed to an international agreement on the reduction of greenhouse emissions. On the agenda of meetings of great powers from world there is an important capitol about the reduction of pollution and protection of environment. On Europe, some of the states took in consideration this concern. For example, on Germany some of the cities forbidden the circulation of diesel cars. Also, Denmark decided that from 2025 will not sale any car which is using the fossil combustion.

Taking in consideration all these concerns, the cars industry tries to adapt, introducing hybrid and electric cars. For a long time period, the change will reduce the pollution on the atmosphere. But this measure must be completed with other ecological commitments.

\footnotetext{
2 ***, Tropical Deforestation and Species Extinction, ed. J. Sayer and Timothy Whitmore (London: Chapman and Hall, 1993); ***, Biodiversity II: Understanding and Protecting our Biological Resources, ed. M.L. ReakaKudla (D.E. Wilson and E.O. Wilson, Washington: Joseph Henry Press, 1997).

${ }^{3}$ Lester Brown et al., State of the World 1998 (W.W. Norton, New York, 1998); World Resources Institute, World Resources, 1998-1999 (New York and Oxford: Oxford University Press, 1998).

${ }^{4}$ Nicolae Mladin, Orest Bucevschi, Constantin Pavel, Ioan Zăgrean, Teologia Morală Ortodoxă (Orthodox Christian Morality), volume II (Alba Iulia: Reîntregirea Publishing House, 2003), 146.

${ }^{5}$ Ian G. Barbour, "Scientific and Religious Perspectives on Sustainability", Christianity and Ecology. Seeking the well-being of Earth and Humans, edited by Dieter T. Hessel and Rosemary Radford Ruether (Cambridge, Massachusetts, 2000), 387.
} 
After an industrialized period, when the nations practiced an intensive agriculture using chemical fertilizers and pesticides, combined with monoculture using artificially produced hybrids, thinkers as Wes Jackson and Wendell Berry proposed to return to traditional, small- and medium-scale farming methods, that used crop rotation and biological methods. These methods will help to develop organic farms with benefits for all: land, plants, animals and human being.

On industry, profit-driven technologies that pollute the global elemental energy circles and generate catastrophic amounts of toxic and non-recyclable wastes will be replaced by appropriate technologies, called "soft energy paths" by Amory Lovins 6 . The wastes of this industrial process will be reusable or recyclable. Technology will not be directed to consumerism, will be redirected to the protection and restoration of damaged ecosystems.

\section{RELIGIONS' WORKS ON THE ENVIRONMENTAL CHALLENGE}

Confronted with ecological crisis, religions as the entire human kind, developed own point of view, starting from their understanding of life, and relationship with Divinity. Christian Church gives on expression of its concern for the nature and for entire cosmos. The Biblical writings affirm the value of the natural world. Created as God's image, human being has capacity and responsibility for nature.

The Biblical perspective of creation, shared by Judaism and Christianity, started from God's creation from nothing (ex nihilo). Only God is and has the existence. He is Creator of everything through His Word or His Son (Colossians 1, 15-16). The Holy Spirit was moving on the face of the waters (Genesis 1,2), on the biblical description. The Holy Trinity is participating to the world's creation. On the sixth day, God created the man. Created in the image of God, man will "rule over the fish of the sea and over the birds of the air and over the cattle and over all the earth and over every living thing which goes flat on the earth" (Genesis 1, 26). This kind of leadership demands responsibility and involvement for entire creation. "The human person must be associated with, and not dissociated from, the created world, for it is through the human person that the created world must be transformed and offered to God. And so the world is freed from its natural limitations and becomes a bearer of life" $"$.

On the other hand, Ian McHarg's raises some critics about Christian thoughts: "Judaism and Christianity have long been concerned with justice and compassion for the acts of the man to man, but have traditionally assumed nature to be a mere backdrop for the human play" ${ }^{\text {. }}$. Unfortunately, this kind of critics starts from poor understanding of Bible and theological thinking. "Eastern theological thought has been concerned with the metahistorical or the spiritual dimensions of this world seen in the light of the kingdom of heaven and the liturgical nature of time. Facts and figures are considered in terms of the Holy

\footnotetext{
${ }^{6}$ Amory Lovins, Soft Energy Paths: Towards a Durable Peace (Harmondsworth: Penguin Books, 1977).

7 John Chryssavgis, "The World of the Icon and Creation: An Orthodox Perspective on Ecology and Pneumatology", Christianity and Ecology. Seeking the well-being of Earth and Humans, edited by Dieter T. Hessel and Rosemary Radford Ruether (Cambridge, Massachusetts, 2000), 85.

${ }^{8}$ Ian L. McHarg, "The Place of Nature in the City of Man", Western Man and Environmental Ethics: Attitudes Toward Nature and Technology, ed. Ian G. Barbour (Reading, Mass: Addison-Wesley, 1973), 175.
} 
Spirit; power is understood from the perspective of the Sacrament of the Eucharist; the world around is appreciated in relation to the heavens above" "9.

Relating to the land, the Western industrial-technological worldview is fundamentally based on the notion of property and ownership. Land is used for farming, herding, building etc. It is not considered as a gift of God made to the human kind, and the human being a steward, not an owner of this world.

On the Eastern thought the man received everything from God, being a steward of entire creation. Creation participates to the Eucharist. Greek metropolitan John Zizioulas believes that "the world is entirely a liturgy, a cosmic liturgy which brings to God's throne entire creation. The orthodox theology is a doxology, a liturgical expression; is a Eucharistic theology"10.

Humanity is responsible for entire creation. The creation of God and human being are interconnected and can become holy, as the Orthodox theology emphasizes. Human being and nature are not in opposition. They have a real relationship. On this relation, man, if wants to overcome the ecological crisis, must become a liturgical being.

On the same time, Christians live on this world using the ascetic theology. Through asceticism, he is not against material world, he is against "own will", which mean personal satisfaction. Christian Church not believes that the material world is bad, as the Gnosticism believes. The material goods can be used for the benefits of man, without exhausting that.

The Orthodox theology has a quite different understanding by an animistic religions or pantheist believe. "In the animistic religious view of primordial peoples all of nature animals, plants, mountains, forests, streams, landscapes - was animated by living intelligences (called "spirits"), with which both shamans and ordinary people could be in communication" 1 . In Ralph Metzner's consideration "by destroying pagan animism and the shamanic traditions preserved in witchcraft, Christianity drastically severed itself from the roots of a regenerative spirituality grounded in the natural world" 12 .

The pantheism (everything is divine) or panentheism (the divine is in everything) are in contraction with Christian understandings of world. The confusion between creation and Creator is presented on the writings of contemporaneous scholars. For example, Alfred North Whitehead believes that God obeys to some general metaphysical principles. "It is not true to say that God is permanent and the world fluent, as that the World is permanent and God is fluent. It is as true to say that God is one and the World many, as that the World is one and God many. It is as true to say that, in comparison with the World, God is actual eminently, as that, in comparison with God, the World is actual eminently. It is as true to say that the World is immanent in God, as that God is immanent in the World. It is as true to say that God transcends the World, as that the World transcends God. It is as true to say that God creates the World, as that the World creates God"13.

\footnotetext{
9 John Chryssavgis, "The World of the Icon and Creation: An Orthodox Perspective on Ecology and Pneumatology", 91.

${ }^{10}$ Ioannis Zizioulas, Creaţia ca euharistie (Creation as Eucharist) (Byzantine Publishing House: Bucharest, 1999), 11.

${ }^{11}$ Ralph Metzner, "The Emerging Ecological Worldview", Worldviews and Ecology. Religion, Philosophy and Environment, Edited by Mary Evelyn Tucker and John A. Grim (Maryknoll New York: Orbis Books, 1999), 167.

${ }^{12}$ Ralph Metzner, “The Emerging Ecological Worldview”, 167.

13 Alfred North Whitehead, Process and Reality: An Essay in Cosmology, edition by David Ray and Donald W. Sherburne (New York: The Free Press, 1978), 348.
} 
In comparison with him, Saint John Chrysostom believes that someone who loses himself on the admiration to the creation, transforms nature into an idol. The world was made with weaknesses, so that everybody can see in that a sign for the care of God to the human being. On this way, human being can avoid the trap of idolatry ${ }^{14}$. Through its magnificence, the universe reveals something from the divine magnificence. Also, being imperfect, the universe cannot allow a confusion between creature and Creator.

On the context of ecological crisis, on Western tradition appeared some writers who speak about "animal gospel" ". In comparison with this understanding, we see today, how our dogs and cats are better fed than most of the children in Africa. The current international economic order tends to perpetuate the third world's role as a supplier of raw materials and cheap labor.

On relation with nature, man changes his attitude. The legends of Prometheus, Faust and Frankenstein all point to the dangers in the search for unlimited power. Christian religion proposes a different one: humility and moderation. Humility requires recognition of limitations in human character and social institutions as well as ecological limits. The natural resources are not limited. If we will waste them, if we will consume more than we need, we will exhaust them. On the time when we waste supplies, other people suffer by hunger and thirsty.

\section{CONCLUSION}

On the dialogue between science and religion, the ecological crisis represents one of the most important points of reflection. If the scientists are thinking in the terms of long time, the biologists and ecologists over many generations, religious traditions are taken in consideration a long-term view. It is necessary a common action for the benefit of all.

The scientific and religious community should cooperate for the benefit of society and the environment. Interdisciplinary dialogue has a good result in education and political decisions. The religious members listen the scientific research and conclusions, and help in spreading the word. Scientists bring the specific information about environment impact, and the religious members share a long-term global view, taking care of nature, as God's creation.

\section{BIBLIOGRAPHY:}

[1] ***, Tropical Deforestation and Species Extinction, ed. J. Sayer and Timothy Whitmore (London: Chapman and Hall, 1993)

[2] ***, Biodiversity II: Understanding and Protecting our Biological Resources, ed. M.L. ReakaKudla (D.E. Wilson and E.O. Wilson, Washington: Joseph Henry Press, 1997).

[3] Andrey Chapman and Rodney Petersen, Consumption, Population and Sustainability: perspective from Science and Religion (Covelo, Calif: Island Press, 2000).

[4] Lester Brown et al., State of the World 1998 (W.W. Norton, New York, 1998); World Resources Institute, World Resources, 1998-1999 (New York and Oxford: Oxford University Press, 1998).

[5] Nicolae Mladin, Orest Bucevschi, Constantin Pavel, Ioan Zăgrean, Teologia Morală Ortodoxă (Orthodox Christian Morality), volume II (Alba Iulia: Reîntregirea Publishing House, 2003).

[6] Ian G. Barbour, "Scientific and Religious Perspectives on Sustainability", Christianity and Ecology. Seeking the well-being of Earth and Humans, edited by Dieter T. Hessel and Rosemary Radford Ruether (Cambridge, Massachusetts, 2000).

\footnotetext{
${ }^{14}$ Saint John Chrysostom, Semons sur la Genèse, collection Source Chretienne, 433 (Paris: Les Éditions du CERF, 1998), 36-38.

${ }^{15}$ Andrew Linzey, Animal Gospel (Louisville, Kentucky: Westminster John Knox Press, 2000).
} 
[7] Amory Lovins, Soft Energy Paths: Towards a Durable Peace (Harmondsworth: Penguin Books, 1977).

[8] John Chryssavgis, "The World of the Icon and Creation: An Orthodox Perspective on Ecology and Pneumatology", Christianity and Ecology. Seeking the well-being of Earth and Humans, edited by Dieter T. Hessel and Rosemary Radford Ruether (Cambridge, Massachusetts, 2000).

[9] Ian L. McHarg, "The Place of Nature in the City of Man", Western Man and Environmental Ethics: Attitudes Toward Nature and Technology, ed. Ian G. Barbour (Reading, Mass: AddisonWesley, 1973).

[10] Ioannis Zizioulas, Creaţia ca euharistie (Creation as Eucharist) (Byzantine Publishing House: Bucharest, 1999).

[11]Ralph Metzner, "The Emerging Ecological Worldview", Worldviews and Ecology. Religion, Philosophy and Environment, Edited by Mary Evelyn Tucker and John A. Grim (Maryknoll New York: Orbis Books, 1999).

[12] Alfred North Whitehead, Process and Reality: An Essay in Cosmology, edition by David Ray and Donald W. Sherburne (New York: The Free Press, 1978).

[13] Saint John Chrysostom, Semons sur la Genèse, collection Source Chretienne, 433 (Paris: Les Éditions du CERF, 1998).

[14] Andrew Linzey, Animal Gospel (Louisville, Kentucky: Westminster John Knox Press, 2000). 